\title{
Erratum to: Tree Height Influences Flight of Lesser Peachtree Borer and Peachtree Borer (Lepidoptera: Sesiidae) Males
}

\author{
Ted E. Cottrell • D. L. Horton • J. Fuest
}

Published online: 20 August 2010

(C) Springer Science+Business Media, LLC 2010

Erratum to: J Insect Behav (2010) 23:329-339

DOI 10.1007/s10905-010-9212-1

The original version of this article unfortunately contained a mistake in the images of both Figures 1 and 2. The corrected images are shown below

Fig. 1 Average number of male $S$. pictipes captured in peach orchards over $4 \mathrm{wk}$ using pheromone-baited traps placed $0 \mathrm{~m}, 1.8 \mathrm{~m}, 3.6 \mathrm{~m}$ and $5.5 \mathrm{~m}$ above ground. In peach orchards, traps at $1.8 \mathrm{~m}$ were within the canopy zone, whereas, traps at $0 \mathrm{~m}$ and $3.6 \mathrm{~m}$ or $5.5 \mathrm{~m}$ were below and above the orchard canopy, respectively. All traps in woods were within the understory. Upper or lower case letters above columns separately indicate significant difference $(P<0.05)$ in capture at different trap heights in orchards or woods, respectively. *, indicates significant difference $(P<0.05)$ between paired columns

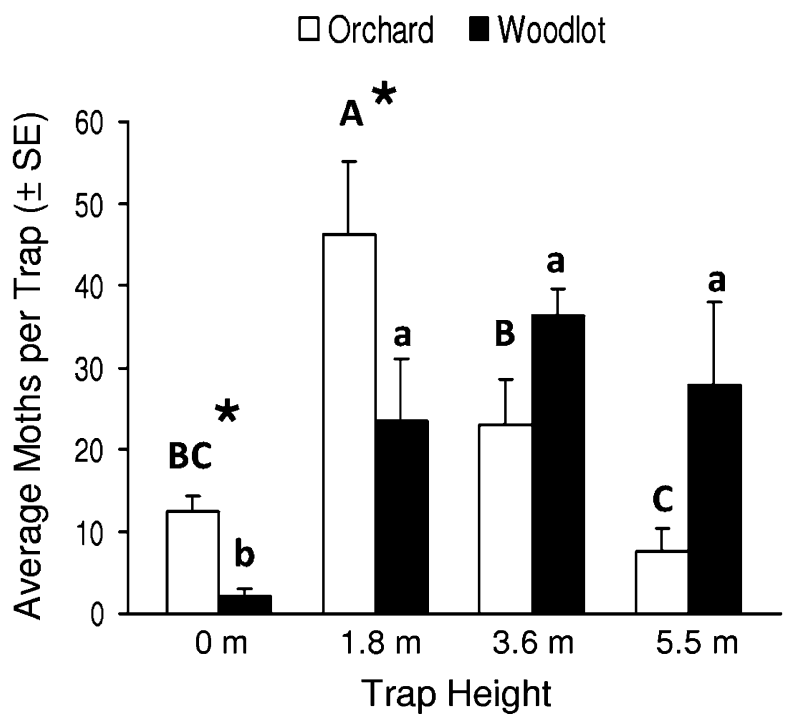

The online version of the original article can be found under http://dx.doi.org/10.1007/s10905-010-9212-1.

T. E. Cottrell $(\bowtie)$

USDA, Agricultural Research Service, Southeastern Fruit and Tree Nut Research Laboratory,

21 Dunbar Road, Byron, GA 31008, USA

e-mail: ted.cottrell@ars.usda.gov

D. L. Horton · J. Fuest

Department of Entomology, University of Georgia, 463 Biological Sciences Building, Athens, GA 30602, USA 
Fig. 2 Average number of male $S$. exitiosa captured in peach orchards over 4 wk using pheromone-baited traps placed $0 \mathrm{~m}, 1.8 \mathrm{~m}, 3.6 \mathrm{~m}$ and $5.5 \mathrm{~m}$ above ground. In peach orchards, traps at $1.8 \mathrm{~m}$ were within the canopy zone, whereas, traps at $0 \mathrm{~m}$ and $3.6 \mathrm{~m}$ or $5.5 \mathrm{~m}$ were below and above the orchard canopy, respectively. All traps in woods were within the understory. Upper or lower case letters above columns separately indicate significant difference $(P<$ $0.05)$ in capture at different trap heights in orchards or woods, respectively. ${ }^{*}$, indicates significant difference $(P<0.05)$ between paired columns
口Orchard Woodlot

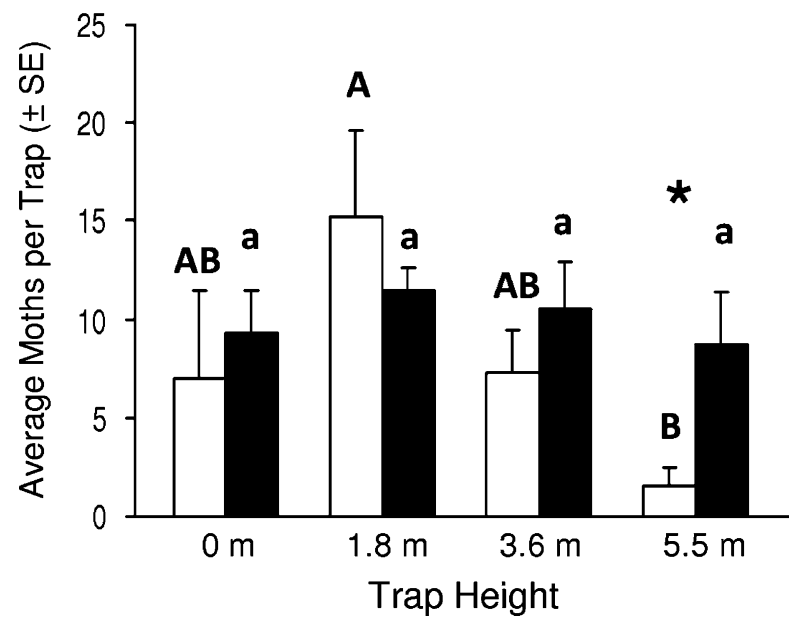

